\title{
LA ACCIÓN PENAL REGULADA EN EL ARTíCULO 162 DEL Código Tributario
}

[The criminal action regulated in article 162 of the Tax Code]

\author{
Raúl NúNez OJeda* \\ Pontificia Universidad Católica de Valparaíso \\ Manuel Silva Salse**
}

\begin{abstract}
RESUMEN
El presente trabajo tiene por objeto el estudio de la acción penal regulada en el artículo 162 del Código Tributario. La primera parte trata el contenido normativo del artículo. La segunda parte se dedica al estudio de la acción penal, sus características, tipos y fundamentos. Luego, se analiza una categoría poco difundida en nuestro país: la acción penal que requiere de autorización de un ente estatal; la que se entiende, corresponde a esta acción penal. Además,
\end{abstract}

\begin{abstract}
The purpose of this paper is to study the criminal action regulated in Article 162 of the Tax Code. The first part deals with the normative content of the article. The second part is dedicated to the study of criminal action, its characteristics, types and foundations. Then, a category little known in our country is analyzed: the criminal action that requires authorization from a state entity; what is understood, corresponds to this criminal action. In addition, a section on proce-
\end{abstract}

Recibido el 4 de abril de 2018 y Aprobado el 8 de noviembre de 2018

* Abogado, Licenciado en Ciencias Jurídicas por la Universidad de Valparaíso. Doctor en Derecho por la Universidad Pompeu Fabra de Barcelona (España). Profesor de Derecho Procesal Civil y Procesal Penal en la Pontifica Universidad Católica de Valparaíso. Correo electrónico: raul.nunez@pucv.cl.

** Abogado, Licenciado en Ciencias Jurídicas por la Pontificia Universidad Católica de Valparaíso. Ex ayudante de Derecho Penal y Procesal Penal en la Pontificia Universidad Católica de Valparaíso. Colaborador del profesor Raúl Núnez Ojeda. Correo electrónico: manuelalberto.ss@gmail.com. 
se incorpora un apartado sobre los presupuestos procesales de perseguibilidad para complementar la visión anterior y las herramientas procesales que pueden ejercerse en caso de que no concurra aquél. La tercera y última parte se dedica a los delitos tributarios y su vinculación con la acción penal.

\section{Palabras clave}

Acción penal - Servicio de Impuestos Internos - delitos tributarios - Derecho penal. dural persecutability budgets is added to complement the previous vision and the procedural tools that may be exercised in the event of non-concurrence. The third and last part is devoted to tax crimes and their connection with criminal action.

\section{KEYWORDS}

Criminal action - Internal Tax Service - tax crimes - Criminal Law.

\section{INTRODUCIÓN}

El artículo 162 del Código Tributario otorga al Servicio de Impuestos Internos la facultad privativa de interponer una denuncia o querella en caso de que durante la investigación por infracciones tributarias descubra que éstas pueden ser constitutivas de delito. En otros términos, el titular de la acción penal por delitos tributarios es el Servicio de Impuestos Internos.

Tradicionalmente, se contemplan tres clases de acción penal: acción penal pública, acción penal pública previa instancia particular y acción penal privada. Si bien éstas son las acciones que reconoce expresamente nuestra legislación procesal penal, doctrinariamente encontramos una cuarta categoría de acción penal que cuenta con reconocimiento implícito en nuestro ordenamiento jurídico: la acción penal que requiere de autorización de un ente estatal. Ésta, si bien es similar a la acción penal previa instancia particular, tiene algunas particularidades que la distinguen de aquélla.

En el presente trabajo se analiza la institución de la acción penal, su naturaleza y fundamentos. Luego, se caracteriza a la acción penal del artículo 162 del Código Tributario como una que requiere autorización de un ente estatal.

Más allá de una mera clasificación, nos permite comprender el trasfondo de su existencia, que está muy relacionada con los delitos tributarios, como se verá: esta autorización tiene sentido porque permite el ejercicio de la acción penal para perseguir delitos tributarios.

Junto con lo anterior, se complementa el estudio procesal con los presupuestos de perseguibilidad, que son aquellos requisitos formales que requiere una relación procesal para que surja válidamente. La autorización del ente estatal, en definitiva, se traduce en uno de aquellos presupuestos. Ahora bien, ¿qué herramientas procesales pueden ejercerse en caso de que falte uno de estos presupuestos? Ello será respondido in infra.

Por tanto, el presente trabajo consiste en un estudio eminentemente dogmático, que analiza la institución desde una perspectiva procesal y 
sustantiva. En este sentido, existe una evidente vinculación entre ambas disciplinas. Particularmente, concurre una estrecha relación entre el Derecho penal y el Derecho procesal penal como corresponsables de la configuración de la política criminal ${ }^{1}$. Desde esta perspectiva, en el último apartado se vincula la acción penal con los delitos tributarios, ya que la denuncia o querella debe cumplir con cierta característica para que sea válida pues se trata de un delito especial.

\section{El artículo 162 del Código Tributario²}

Como se adelantó en la introducción, la norma fundamental en relación con el ejercicio de la acción penal en materia tributaria se encuentra en el artículo 162 del Código Tributario. Constituye una excepción a

${ }^{1}$ Cfr. Binder, Alberto, Introducción al Derecho procesal penal (2a edición, Buenos Aires, Ad Hoc, 2000), pp. 41 ss.

2 Piedrabuena Richard, en su artículo titulado "Las potestades del Ministerio Público en la investigación de los delitos tributarios", publicado en dos revistas diferentes (Piedrabuena Richard, Guillermo, Las potestades del Ministerio Público en la investigación de los delitos tributarios, en Revista de Derecho del Consejo de Defensa del Estado 33 (2015), pp. 11-68; y Piedrabuena Richard, Guillermo, Las potestades del Ministerio Público en la investigación de los delitos tributarios, en Revista de Derecho Público 85 (2016), pp. 115-153. Las referencias posteriores serán a la última publicación), plantea: "la derogación tácita de la facultad exclusiva del Director del SII para decidir en forma autónoma el inicio de una investigación penal por un posible delito tributario, dictada la reforma constitucional que creo [creó] el Ministerio Público y la naturaleza del delito de acción penal público [pública] del delito tributario" (p. 115). En contra, Salazar Cádiz, Andrés, Acerca del inicio del proceso penal por delitos tributarios: análisis de la posición del profesor Piedrabuena en relación con las facultades de investigación del Ministerio Público en ausencia de querella o denuncia del Servicio de Impuesto Internos, en Revista Jurídica del Ministerio Público 66 (2016), pp. 179-204; analiza, a nuestro juicio correctamente, desde una perspectiva crítica la tesis del referido autor: "anticipando el juicio de valor [...] es posible indicar que el trabajo de Piedrabuena exhibe ciertos problemas a nivel de justificación externa (esto es, de fundamentación de premisas) e interna (a nivel de conclusiones) y por lo tanto, no provee un resultado consistente que permita cimentar adecuadamente la hipótesis por él bosquejada" (p. 179). En síntesis, si la tesis de Piedrabuena "estuviese en lo correcto, deberíamos llegar a considerar, de manera consecuente, que todas las facultades investigativas, de todos los órganos del Estado que puedan vincularse, de cualquier forma, con la averiguación de hechos que revisten carácter de delito, son necesariamente investigaciones penales y, por lo tanto, han quedado derogadas por efecto de la publicación de la Ley $\mathrm{N}^{\circ} 19.519$ [...] entonces deberíamos denunciar con la misma fuerza la inconstitucionalidad de la actuación de todos los jefes de servicios públicos [...], la Contraloría General de la República [...], la Superintendencia de Valores y Seguros [...], la Fiscalía Nacional Económica” (p. 197). En consecuencia, "no es posible pretender torcerle la mano al ordenamiento jurídico, cuando el diseńo institucional dispuesto por éste se encuentra claramente orientado en el sentido de restringir dichas posibilidades de actuación" (p. 204). 
lo prescrito por los artículos 53 y 172 del Código Procesal Penal, pues la investigación de hechos que revisten caracteres de delitos tributarios únicamente puede ser iniciada por denuncia o querella del Servicio de Impuestos Internos, o por querella del Consejo de Defensa del Estado a requerimiento de éste, en su caso ${ }^{3}$.

El inciso primero del citado artículo establece expresamente la facultad privativa del Servicio de Impuestos Internos para ejercer la acción penal por la eventual comisión de delitos tributarios. Ésta es la única forma en la que el Ministerio Público puede iniciar una investigación por su eventual comisión ${ }^{4}$. Como reconoce el Ministerio Público, el adverbio "sólo" resulta indicativo de la evidente decisión legislativa de excluir la posibilidad de iniciar de oficio la persecución penal ${ }^{5}$.

En consecuencia, esta norma establece un régimen especial de inicio del procedimiento penal respecto de los delitos tributarios, apartándose de las formas usuales de ejercicio de la acción penal ${ }^{6}$.

En particular, esta facultad la debe ejercer el Director del Servicio de Impuestos Internos (artículo 7 letra g) de la Ley Orgánica del Servicio de Impuestos Internos ${ }^{7}$.

Conforme al inciso tercero del artículo 162 del Código Tributario, en caso de que la infracción sea sancionada tanto con multa como con pena privativa de libertad, se otorga al Director del Servicio la facultad discrecional para ejercer la acción penal (mediante la presentación de una denuncia o querella), o bien, perseguir sólo la aplicación de la multa

3 Vid. Van Weezel, Alex, Delitos tributarios (Santiago, Editorial Jurídica de Chile, 2007), p. 165.

4 "Las razones esgrimidas fueron muchas para que el Director del SII -y no el Ministerio Público- mantuviese la exclusividad de tan relevante facultad. En especial, se tuvo en consideración: el evidente conflicto entre el cobro civil de los impuestos y los delitos tributarios, la falta de certeza jurídica y el entorpecimiento de la actividad recaudadora, lo cual podría traer como consecuencia una menor recaudación impositiva. En definitiva, que el Ministerio Público tenga esta facultad era riesgoso sobre todo por su falta de experticia tributaria, además de la obvia superposición de funciones y facultades que ello implicaría, ruptura de la armonía y justicia del sistema tributario. Aquello podría degenerar en una potencial vulneración de la garantía del debido proceso, además del hecho que si el Ministerio Público inicia la querella en medio del proceso fiscalizador, éste queda inconcluso y se pierde la oportunidad de recaudar". Vila Baltra, Martín, Titularidad de la acción penal en los delitos tributarios, en Anuario de Derecho Tributario 7 (2015), p. 65.

5 "Instrucción general que imparte criterios de actuación del Ministerio Público en la investigación de los delitos tributarios, en relación con lo dispuesto por el artículo 162 del Código Tributario", oficio N487/2016, p. 3.

${ }^{6}$ Cfr. Ibid., p. 1.

7 DFL N 7 del Ministerio de Hacienda, de 1980. 
correspondiente. Se trata de una facultad que el Director puede ejercer discrecionalmente $y$, en tal sentido, la resolución que adopte no es susceptible de reclamación ni de recurso alguno ${ }^{8}$. Además, la gran mayoría de los delitos tributarios son sancionados con multa y pena privativa de libertad, siendo la regla general.

Por su parte, el inciso sexto del artículo 162 del Código Tributario impone al Ministerio Público la obligación de informar al Servicio de Impuestos Internos los antecedentes que tomaré conocimiento y que pudieren relacionarse con delitos tributarios. Con ello se reafirma que el Ministerio Público, para llevar adelante una investigación por un delito tributario, se encuentra limitado por la decisión previa que adopte el Servicio en relación con el ejercicio de la acción penal.

Esta regulación es concordante con lo dispuesto en el Derecho comparado y en las normas del Centro Interamericano de Administraciones Tributarias (CIAT) ${ }^{9}$. En particular, el artículo 174 del modelo de Código Tributario del CIAT, organismo del cual Chile es parte desde 1967, propone que: "Las acciones penales por delitos tributarios ante la justicia ordinaria serán iniciadas por querella o denuncia del titular de la Administración tributaria...".

En síntesis, se trata de una acción penal de ejercicio privativo ${ }^{10} \mathrm{y}$ discreciona ${ }^{11}$ del Servicio de Impuestos Internos.

Es más, Massone afirma que "en materia tributaria, no existe delito si el Director del Servicio de Impuestos Internos, en uso de su facultad discrecional, opta por no ejercer la acción penal" 12 y en atención "al carácter definitivo de la decisión del Director, el delito deja de ser tal, se convierte, a lo más, en infracción administrativa, en el sentido de que está enteramente sometido al régimen jurídico de esta última"13.

Por otro lado, el Servicio de Impuestos Internos debe manifestar su voluntad, como todo órgano de la Administración del Estado, por medio de un acto administrativo (artículo $3^{\circ}$ de la Ley $\mathrm{N}^{\circ} 19.880$ de bases del

${ }^{8}$ Circular $N^{\circ} 40$, de 20 de junio de 2002, pronunciada por el Director del Servicio de Impuestos Internos, p. 24.

9 Vila Baltra, Martín, cit. (n. 4), p. 63.

10 "Por tratarse de un delito de acción "privativa", ninguna otra persona o autoridad podrá requerir al Ministerio Público para que inicie la investigación de esta clase de ilícitos", Circular No 40, de 20 de junio de 2002, pronunciada por el Director del Servicio de Impuestos Internos, p. 22. También queda en evidencia en el contenido de las querellas que interpone el Servicio.

${ }^{11}$ En este sentido, Van Weezel, Alex, cit. (n. 3), p. 165.

${ }^{12}$ Massone Parodi, Pedro, Infracciones tributarias (2a edición, Santiago, Legal Publishing, 2010), p.326.

${ }^{13}$ Ibid., p. 327. 
procedimiento administrativo ${ }^{14}$, el cual constituye un acto terminal del proceso administrativo de recopilación de antecedentes. Éste, luego, se traducirá en una denuncia o querella por parte del Servicio, si decide ejercer la acción penal.

\section{LA ACCIÓN PENAL}

a) Aspectos generales ${ }^{15}$. En la actualidad, la acción en el proceso penal ha sido poco tratada en la dogmática comparada. LEONE, por ejemplo, manifestaba que la fatigosa elaboración del concepto de acción en el Derecho procesal civil sólo puede aspirar a servir para fijar meras premisas en aras a determinar un concepto de acción penal; resultando el resto de la referida elaboración completamente ajena al ámbito del enjuiciamiento criminal ${ }^{16}$.

La dogmática procesal penal alemana abandonó, hace ya mucho

${ }^{14}$ En este sentido, Massone afirma que: "la decisión del Director en [es] un acto administrativo, sin perjuicio que su cumplimiento pueda llevar envuelta la realización de actos procesales. Es además un acto definitivo e irrevocable y, en todo caso, no puede cambiarse en perjuicio el [del] supuesto infractor". Ibid., p. 326. Acerca del acto administrativo, ver: Bermúdez, Jorge, Derecho Administrativo general (2a edición, Santiago, LegalPublishing, 2011), pp. 108 ss.

15 En general, los manuales nacionales se limitan a reproducir las normas en cuestión: Castro Jofré, Javier, Introducción al Derecho Procesal Penal chileno (2a edición, Santiago, LegalPublishing, 2008), pp. 405 ss.; Chahuán Sarras, Sabas, Manual del nuevo procedimiento penal (7a edición, Santiago, LegalPublishing, 2012), pp. 164-166; Correa Selamé, Jorge, Curso de derecho procesal penal (Santiago, Ediciones Jurídicas de Santiago, 2003), pp. 97-99; Horvitz Lennon, María Inés - López Masle, Julián, Derecho procesal penal chileno (Santiago, Editorial Jurídica de Chile, 2002), I, p. 333 ss.; Maturana Miquel, Cristián - Montero López, Raúl, Derecho procesal penal (Santiago, LegalPublishing, 2010), I, pp. 336 ss; Otero Lathrop, Miguel, La policía frente al Código Procesal Penal (Santiago, Editorial Jurídica de Chile, 2010), pp. 51-53; Silva Montes, Rodrigo, Manual de procedimiento penal (Santiago, Editorial Jurídica de Chile, 2001), pp. 33-35.

Otros autores, no tratan el tema en sus manuales: Carocca Pérez, Álex, $M a-$ nual. El nuevo sistema procesal penal (4 ${ }^{\text {a }}$ edición, Santiago, LexisNexis, 2008); DucE Julio, Mauricio - Riego Ramírez, Cristián, Proceso penal (Santiago, Editorial Jurídica de Chile, 2007); Medina Jara, Rodrigo - Morales Palacios, Luis - Dorn Garrido, Carlos, Manual de derecho procesal penal (2a edición, LexisNexis, Santiago, 2007).

${ }^{16}$ Leone, Giovanni, Azione penale, en Enciclopedia del Diritto IV (Milano, Giuffrè, 1958), p. 851. En el mismo sentido, entre otros: Dominioni, Oreste, Azione Penale, en Digesto della Discipline Penalistiche (Torino, UTET, 1987), p. 399; Chiavario, Mario, L'azione penale tra e Diritto e Politica (Padova, CEDAM, 1995), pp. 17 y 18; y, Cordero, Franco, Procedure Penale (5ºdición, Milano, Giuffrè, 2000), pp. 393 ss. 
tiempo, los conceptos de acción penal (Strafklage) y de pretensión penal $(\text { Strafanspruch })^{17}$. Así las cosas, Wolfslast ${ }^{18}$ señala que no hay una pretensión penal estatal como derecho subjetivo del Estado de penar en la estrecha concepción del Derecho Civil. El concepto de derecho penal subjetivo o el derecho subjetivo de penar debería ser evitado por los problemas que esta terminología conlleva.

Para esta autora, el concepto de pretensión penal pública comprende ${ }^{19}$ : i) primero, la específica competencia del Estado para intervenir sobre los derechos de un delincuente concreto, que en un Estado de Derecho viene regulada por la Ley; ii) segundo, el soberano, universal y monopólico derecho del Estado de persecución penal y castigo, como expresión del monopolio estatal de poder y justicia y de la ejecución del deber del Estado; iii) tercero, la parte estatal de la relación jurídico-penal material entre el Estado y delincuente; y iv) cuarto, el general y concreto deber del Estado de penar o de sancionar.

El profesor Roxin ${ }^{20}$ mantiene una posición similar. En este sentido adiciona la imposibilidad de establecer un paralelismo entre la pretensión penal del Estado en el enjuiciamiento criminal y la pretensión de los actores en el proceso civil. Para este autor este paralelismo sólo representaría un circunloquio conceptual del poder de intervención del Estado ${ }^{21}$.

${ }^{17}$ Uno de los escasos aportes doctrinales alemanes recientes en esta materia provienen de H. Kaufmann (Kaufmann, Hilde, Strafanspruch, Strafklagerecht (Göttingen, Otto Scwartz Verlag, 1968), p. 130) para quien el concepto de derecho de acción penal (Strafklegerecht) es un componente histórico dogmático de la idea de acción (Aktion), que en el moderno pensamiento jurídico habría devenido inaplicable con el abandono de aquel concepto de Aktion.

La explicación es sencilla, en Alemania la inexistencia de una posible actividad acusadora por parte de los particulares (ofendido como ningún otro) ha hecho inútil en este sentido la construcción por parte de la dogmática de un concepto de acción penal como demanda de una decisión. En el mismo sentido respecto de la doctrina italiana: Dominioni, Oreste, cit. (n. 16), p. 399.

18 Wolflast, Gabriele, Staatlicher Strafanspruch und Verwirkung (Köln, Carl Heymanns, 1995), pp. 57 ss.

${ }^{19}$ Ibid., p. 98.

${ }^{20}$ Roxin, Claus, Strafverfahrensrecht (25 edición, München, CH. Beck, 1998), p. 6.

${ }^{21}$ Para el profesor alemán Volk (VoLK, Klaus, Strafprozeßrecht (München, CH. Beck, 1999), p. 3) no tiene mucho sentido (pero es común) hablar de una pretensión penal del Estado que se realizaría en el proceso. El delito no genera una pretensión penal. El autor no puede realizarlo o excepcionarlo. Así las cosas, en Derecho Penal se puede decir que el autor ha actuado culpablemente, pero difícilmente que por ello debe algo al Estado. Por tanto, mientras éste no sea declarado culpable por sentencia firme no debe nada al Estado. También considera que no es posible hablar de preten- 
Sólo recientemente, en Italia se ha comenzado a discutir, otra vez, el concepto de acción penal, pero desde un punto de vista nuevo ${ }^{22}$. Frente a la perspectiva histórica tradicionalmente adoptada, el debate queda reducido al plano meramente normativo ${ }^{23}$. Desde esta nueva perspectiva, la acción penal sería una demanda de resolución jurisdiccional, cuyo contenido debe elaborarse en atención a las específicas previsiones normativas ${ }^{24}$. Esta posición está demostrando la imposibilidad de estructurar un concepto de acción penal meramente teórico, y, por lo mismo, válido universalmente, alejado del ordenamiento positivo ${ }^{25-26}$.

Por tanto, el concepto de acción penal tiene por única función determinar el momento en que se puede iniciar la persecución penal; es en este

sión penal en el sentido dado por la ciencia procesal civil: ZIpF, Heinz, Strafantrag, Privatklage und staatlicher Strafanspruch, en GA (1969), pp. 234 ss.

22 Para un estudio del concepto de acción penal y su relación con el concepto de acción civil en Italia, confrontar por todos: ChIAvario, Mario, cit. (n. 16), pp. 3 ss.

${ }^{23}$ VAlentini Reuter, Cristina, Le forme di controllo sull'esercizio dell'azione penale (Padova, CEDAM, 1994), p. 26. En el mismo sentido: Chiavario, Mario, Appunti sul processo penale (Torino, Giappichelli, 2000), p. 109; Tonini, Paolo, Manuale di procedura penale (Milano, Giuffrè, 1999), p. 49; y, Riccio, Giuseppe, Azione penale e politica delle reforme, en Arch.pen. (1992), p. 381. También existen autores que niegan cualquier elaboración conceptual de la acción penal, incluso como mera demanda de decisión jurisdiccional: Taormina, Carlo, Vecchio e nuovo nella teoria dell'azione penale» alle soglie del nuovo codice di procedura, en La Giustizia Penale (1988), pp. 129 ss.

${ }^{24}$ En este senido ver: Morello, Michele, Il nuovo processo penale. Parte generale (Padova, CEDAM, 2000), pp. 47 ss.

25 Bellavista, Girolamo - Tranchina, Giovanni, Lezione di Diritto Processuale Penale (10º edición, Milano, Giuffrè, 1987), pp. 45 ss.; y, Leone, Grovanni, cit. (n. 16), pp. 852 ss.

${ }^{26}$ Con todo, es menester aclarar que cuando nos referimos a acción penal no se puede entender igual que el concepto clásico que se maneja en la teoría general del proceso. En primer lugar, si se analiza la función del Ministerio Público, no se puede afirmar que éste tenga un derecho a su favor, sino un deber de ejercer la acción penal pública. En segundo lugar, cuando se ejerce la acción penal no se busca la tutela de derechos individuales, sino que se haga efectivo el ius puniendi. En tercer lugar, cuando la ley utiliza la expresión acción penal, en ciertas ocasiones, alude a un derecho de iniciativa (por ejemplo, en los delitos de acción privada en los que sólo la víctima podrá ejercer la acción penal; artículos 53 y $400 \mathrm{CPP}$ ). En otras, se refiere a un derecho a la acusación (por ejemplo, en los delitos de acción penal pública en los que el Ministerio Público deberá de oficio, investigar y, en su caso, ejercer la acción penal pública; artículo $83 \mathrm{CPP}$ ). En cuarto lugar, la acción penal se contempla como un presupuesto para la apertura del juicio oral. Oliver Calderón, Guillermo, Apuntes de Derecho Procesal Penal (Valparaíso, inédito, 2017), pp. 90-91. 
sentido en que el Código Procesal Penal chileno distingue la acción penal en los artículos 53 y siguientes ${ }^{27}$.

b) Acción penal pública previa instancia particular. Conforme a nuestro ordenamiento jurídico, la acción penal se puede clasificar en atención al interés prevalente de su ejercicio. Si es de la sociedad, se estará ante una acción pública; en cambio, si es de la víctima, la acción será privada ${ }^{28}$. Luego, cabe distinguir entre delitos de acción pública, de acción penal pública previa instancia particular y de acción privada ${ }^{29}$.

En los delitos de acción penal pública previa instancia particular, el legislador somete el inicio del procedimiento a la voluntad de la víctima, quien debe denunciar ${ }^{30}$ el hecho o deducir una querella ${ }^{31}$. En efecto, como la tramitación del procedimiento o su publicidad podría perjudicar todavía más el interés que se quiere proteger -y que ya se vio dañado con el delito ${ }^{32}$ - el legislador exige una manifestación de voluntad particular. Esta, se transforma en una condición que, sólo una vez cumplida, habilita la acción oficial ${ }^{33}$ del Ministerio Público para la persecución penal.

El artículo 54 del Código Procesal Penal prohíbe al Ministerio Público ejercer la persecución penal de un delito de acción penal pública previa instancia particular sin que antes, a lo menos, el ofendido hubiere denunciado el hecho. En otras palabras, para que el Ministerio Público pueda iniciar la persecución penal de esta clase de delitos se requiere de

${ }^{27}$ Se ha definido la acción penal como "el derecho subjetivo potestativo público que la ley otorga al Ministerio Público y a ciertas personas legitimadas, para requerir del juez, a través del fiscal de dicho Ministerio, una decisión acerca de la noticia de un delito, en orden al establecimiento de su existencia y a su posible imputación a determinada persona a fin de imponer una pena”. NúÑEz VÁsQuez, J. Cristóbal, Tratado del proceso penal y del juicio oral. Introducción al estudio del proceso penal (Santiago, Editorial Jurídica de Chile, 2003), p. 58.

${ }^{28}$ Oliver Calderón, Guillermo, cit. (n. 26), p. 92.

${ }^{29}$ Compartiendo esta clasificación tripartita: CASTRO Jofré, Javier, cit. (n. 15), pp. 405 ss.; Maturana Miquel, Cristián - Montero López, Raúl, cit. (n. 15), pp. 336 ss.

${ }^{30}$ Monográficamente sobre la denuncia ver: Torres Rosell, Nuria, La denuncia en el proceso penal (Madrid, Montecorvo, 1991), passim.

${ }^{31}$ Monográficamente sobre la querella ver: Gimeno Sendra, José Vicente, $L a$ querella (Barcelona, Bosch, 1977), passim.

32 Vélez Mariconde, Alfredo, Derecho Procesal Penal (Córdoba, Lerner, 1986), I, p. 279. También es de la misma opinión: Oliver Calderón, Guillermo cit. (n. 26), p. 93. En este sentido, pero sin incluir el adjetivo preferente: NúNEEZ VÁsQuEZ, J. Cristóbal, cit. (n. 27), p. 65., quien hace la distinción "en cuanto a los intereses generales o particulares que cautela”.

33 Vid. Maier, Julio, Derecho procesal penal (Buenos Aires, Editores del Puerto, 2004), p. 676. 
una denuncia o querella del ofendido como sucede, por ejemplo, respecto de los delitos sexuales contra mayores de edad ${ }^{34}$.

c) Acción penal que requiere autorización de entes estatales. Junto con la clasificación anterior, existe otro tipo de acción penal que se caracteriza por requerir una habilitación por parte de un ente estatal para proceder con la persecución penal. En este sentido, es similar a la acción penal pública previa instancia particular, por cuanto el Ministerio Público necesita de la autorización de un tercero.

Sin embargo, la acción penal pública previa instancia particular opera generalmente sobre el presupuesto de que existe una víctima persona natural. En su mayoría, se trata de delitos que lesionan bienes jurídicos de carácter individual ${ }^{35} \mathrm{y}$ su fund a men to o naturaleza radica en que con la intervención de la víctima ella consiente en la persecución penal. Sólo así se podría evitar que este proceso afecte su honra o intimidad o que vuelva a sufrir nuevamente algún grado de victimización ${ }^{36}$.

En cambio, los delitos que requieren de autorización de entes públicos tienen un fundamento distinto. Conforme a los ámbitos de regulación en los cuales estas acciones penales existen, podemos entender que su fundamento radica en el carácter técnico o especializado de su regulación. En efecto, cada órgano facultado para provocar el inicio de la investigación penal (Fiscalía Nacional Económica ${ }^{37}$, Servicio de Impuestos Internos, etc.) tiene las competencias técnicas para evaluar las particularidades del caso y, así, definir si se han infringido o no sus normas y la naturaleza de

${ }^{34}$ Sobre el ejercicio de la acción penal en los delitos sexuales, ver RodRíguez Collao, Luis, Delitos sexuales (2a edición, Valparaíso, Editorial Jurídica de Chile, 2014), pp. 399 ss.

35 Aquí se ajusta a la visión de Hassemer sobre los llamados bienes jurídicos personalísimos. Para un desarrollo mayor ver: Hassemer, Winfried, Lineamientos de una teoría personal del bien juridico, en Doctrina Penal (1989), pp. 275 ss. Además consultar los trabajos de: Herzog, Felix, Gesellschaftliche Unsicherheit und strafrechtliche Daseinsvorsorge (Heidelberg, RV. Decker, 1991), pp. 116 ss.; y, HoHmann, Olaf, Das Rechtsgut der Unweltdelikte (Frankfurt, Peter Lang, 1991), pp. 58 ss.

${ }^{36}$ En este sentido, el Ministerio Público concuerda en que el fundamento de la institución de la acción penal privada previa instancia particular es la afectación que puede sufrir la víctima en la iniciación del procedimiento penal. Cfr. Oficio de la Fiscalía Nacional No 487 de 2016, p. 2.

37 En virtud de las modificaciones introducidas por la Ley $\mathrm{N}^{\circ} 20.945$ al DFL N ${ }^{\circ}$ 1 de 2005, que fija el texto refundido, coordinado y sistematizado del DL No 211 de 1973. En particular, el nuevo artículo 64. Sobre algunos breves aspectos del proyecto de ley que culminó con esta Ley, ver: Silva Salse, Manuel, Diligencias de investigación limitativas de derechos fundamentales o intrusivas otorgadas a la Fiscalía Nacional Económica, en Revista de Filosofía y Ciencias Jurídicas 7 (2015), pp. 96 ss. Disponible [en línea]: http://www.rfycj.cl/wp-content/uploads/2016/04/RFyCJ-N7-5.pdf]. 
la infracción. Por lo mismo, no se trata de una simple autorización de un ente estatal, sino que además, implica una determinación de los hechos y directrices para su persecución.

La determinación de los alcances de un delito tributario envuelve mayor complejidad que los delitos comunes, toda vez que para determinar si una conducta es encasillable en aquéllos, se requiere de un estudio de la normativa administrativa subyacente y su eventual infracción. Desde esta perspectiva, los delitos tributarios difieren de los delitos comunes, que, si bien pueden ser de difícil acreditación fáctica, no revisten mayor complejidad normativa: bastará con acreditar que los hechos imputados coinciden con la descripción abstracta del tipo penal. En cambio, en los delitos tributarios aquella realidad fáctica también se relaciona estrechamente con la regulación administrativa tributaria. Es decir, los delitos tributarios requieren de ciertos incumplimientos normativos para que se configuren los tipos.

Los delitos tributarios operan al interior de un sistema conformado por normas jurídicas de distinto rango: en el plano legal, Código Tributario, Ley de Impuesto a la Renta, Ley de Donaciones, entre otras; en el plano administrativo, circulares, instrucciones y oficios. Este último tipo de normas tiene por objeto establecer criterios para la interpretación y aplicación de la ley tributaria. En principio, el contribuyente deberá coordinar estas distintas normas para determinar el contenido y alcance de sus obligaciones. De allí que cualquier conducta que pueda eventualmente configurar una infracción tributaria requiera de un estudio previo que permita determinar no sólo el exacto alcance de esta conducta al interior del sistema sino también su eventual configuración como infracción administrativa o como delito ${ }^{38}$.

En este sentido, los tipos penales contenidos en el Código Tributario describen infracciones de deberes cuyo contenido y alcance precisos emanan de la legislación tributaria sustantiva. Es por ello por lo que, para determinar la existencia de una infracción constitutiva de delito, se requiere desarrollar un procedimiento de investigación administrativa que permita resolver cuestiones previas de carácter técnico. Esta determinación del deber fiscal se halla en la base de la mayor parte de los tipos penales y le corresponde primordialmente al Servicio de Impuestos Internos a través de su Director (artículo 6, letra A, $\mathrm{N}^{\circ} 1$ del Código Tributario) ${ }^{39}$.

Al Servicio de Impuesto Internos le corresponde recopilar antecedentes

${ }^{38}$ Laporta H., Mario, Delito fiscal. El hecho punible, determinación del comportamiento típico (Buenos Aires, B. de F., 2013), pp. 87 ss.

39 Van Weezel, Alex, cit. (n. 3), p. 19. 
que han de servir para fundamentar la interposición de una denuncia o querella. Esta etapa de investigación se denomina recopilación de antecedentes, y el Servicio de Impuestos Internos la define como aquella en la que: "se hace acopio de los elementos que se consideren necesarios para que el Director adopte la decisión consagrada en el inciso $3^{\circ}$ del artículo 162 del Código Tributario, vale decir, los antecedentes que demuestren la materialidad de los hechos que puedan configurar un ilícito tributario, así como la participación de las personas involucradas en su ejecución y el monto del perjuicio fiscal, si corresponde ${ }^{240}$. Administrativamente, el proceso de recopilación de antecedentes por delitos tributarios está regulado en la circular $\mathrm{N}^{\circ} 8$, de 14 de enero de $2010^{41}$.

${ }^{40}$ Circular $\mathrm{N}^{\circ} 40$, de 20 de junio de 2002, pronunciada por el Director del Servicio de Impuestos Internos, p. 21.

${ }^{41}$ En síntesis, en ella se establece el siguiente procedimiento para la recopilación de antecedentes: $i$ ) "Detección de hechos eventualmente constitutivos de delito tributario": Todo funcionario que, en ejercicio de sus funciones, tome conocimiento o reciba antecedentes relacionados con hechos posiblemente constitutivos de alguno de los delitos tributarios, deberá remitir dichos antecedentes en forma inmediata al jefe del Departamento o Unidad en que se desempeñe; ii) "Remisión de antecedentes a la jefatura correspondiente": el funcionario que tome conocimiento o reciba antecedentes relacionados con hechos presuntamente constitutivos de delitos tributarios, elaborará una minuta con los antecedentes del caso y un breve análisis de los mismos, la cual será remitida al jefe del Departamento o Unidad de la cual dependa el funcionario informante, quien la evaluará, decidiendo en alguno de los siguientes sentidos: someterla a evaluación del Comité para dar inicio al proceso de recopilación de antecedentes; si los antecedentes reunidos son suficientes para acreditar el hecho delictivo y la participación, sin que sea necesario iniciar un proceso de recopilación, remitirá la minuta y documentación al Jefe del Departamento u Oficina Jurídica; o si la entidad de los hechos referidos en la minuta no posee la suficiencia y calidad para adoptar alguna de las decisiones anteriores, informará en tal sentido al funcionario responsable, disponiendo las medidas que sean pertinentes; iii) "Registro de las irregularidades detectadas": deberá efectuarse en el sistema computacional que en el momento se encuentre vigente; $i v$ ) "Procedimiento de cobro de impuestos": sin perjuicio de lo establecido en los párrafos anteriores, se debe proceder siempre en forma inmediata a la determinación y cobro de los impuestos o diferencias impositivas que existan; $v$ ) "Análisis de los antecedentes por parte del Comité": en cada sesión, el Comité procederá a efectuar el análisis de los casos, el cual deberá adoptar alguna de las siguientes decisiones: ordenar se lleve a cabo una recopilación de antecedentes por delito tributario, disponiendo asimismo el cobro de las diferencias de impuestos que resultaren del proceso, cuando corresponda; o remitir los antecedentes al Departamento que el Comité determine, a objeto que se desarrolle un procedimiento de fiscalización y/o se proceda al cobro de los impuestos adeudados o de las diferencias impositivas, si se presentan y no se hubiere completado, o archive los antecedentes, según corresponda. Para la adopción de alguna de las decisiones indicadas, el Comité deberá considerar especialmente los siguientes factores: monto del perjuicio al inte- 
Los antecedentes que se reúnen durante esta fase permiten al Director Nacional adoptar una decisión que, si bien es discrecional, nunca podría -o debería- llegar a ser arbitraria. En otras palabras, conforme a los principios y normas que reglan los actos de la administración del Estado, el Director del Servicio de Impuestos Internos no puede ejercer válidamente la facultad dispuesta en el artículos 162 del Código Tributario, sin que, al menos, cuente con los antecedentes que le permiten definir: $i$ ) primero, si existe o no una infracción a las disposiciones tributarias; y ii) segundo, si dicha infracción, de acuerdo con los criterios históricos del propio Servicio, merece ser sancionada sólo con multa, o bien, con multa y pena privativa de libertad.

Sobre este último aspecto, cabe agregar que la inobservancia por parte del Servicio de Impuestos Internos de los criterios históricos que ella misma se ha impuesto, puede constituir una vulneración al principio administrativo de protección de la confianza legítima ${ }^{42}$.

Por tanto, es posible concluir que la necesidad de intervención del Servicio de Impuestos Internos está establecida en atención a la especificidad técnica de la materia y no en relación con la intimidad o la honra

rés fiscal comprometido, en aquellos casos en que es posible determinar su cuantía, atendida la realidad regional o del sector; relación del monto del crédito fiscal amparado en los documentos impugnados, con el monto del crédito total empleado en los períodos revisados, cuando pertenezca al ilícito; reiteración en la utilización de facturas falsas en calidad de tenedor, o que el infractor registre participación en casos anteriores como proveedor de las mismas, si corresponde a la conducta detectada; existencia de antecedentes que permitan presumir que ha existido intencionalidad en la conducta delictiva de que se trate; y el efecto ejemplificador o pedagógico que podría alcanzar una eventual persecución penal de los hechos, considerando la realidad regional, el giro o actividad del infractor y la naturaleza del ilícito; vi) "Acta del Comité": las decisiones del Comité constarán en un acta suscrita por el secretario; vii) "Remisión de las actas del Comité": respecto de los casos en que el Comité haya dispuesto efectuar una recopilación de antecedentes, deberá remitir copia del acta respectiva a la unidad encargada de dicho proceso; viii) "Procedimiento a seguir cuando, producto de la recopilación de antecedentes o del procedimiento de fiscalización, se detecten conductas eventualmente constitutivas de delito tributario": se deberán seguir los procedimientos establecidos en las resoluciones $\mathrm{N}^{\circ} 138$ y 139 , ambas de 29 de octubre de 2008, y de las instrucciones que las complementen.

${ }^{42}$ Acerca del principio de protección de la confianza legítima en el Derecho Administrativo, ver: Bermúdez, Jorge, cit. (n. 14), p. 85 ss.; Soto Kloss, Eduardo, Acerca de la obligatoriedad de los precedentes en la actividad administrativa del Estado, en Revista Chilena de Derecho 26 (1999), 2, pp. 399-403; Castillo Blanco, Federico, La protección de la confianza legitima en el Derecho Administrativo (Madrid, Editorial Marcial Pons, 1998), passim. 
de la víctima, como sucede con la mayoría de los delitos de acción penal pública previa instancia particular.

Esta categoría de acción penal tiene un reconocimiento implícito en nuestra legislación ${ }^{43}$. El artículo 264 del Código Procesal Penal regula las excepciones de previo y especial pronunciamiento que pueden ser alegadas en la audiencia de preparación del juicio oral, entre las que se encuentra la "falta de autorización para proceder penalmente, cuando la Constitución o la ley lo exigieren" (letra d). Luego, la inexistencia de denuncia o querella por parte del Servicio de Impuestos Internos implica una falta de autorización para proceder penalmente.

d) Presupuesto procesal de perseguibilidad (condiciones de procedibilidad). Según la doctrina tradicional, las condiciones de procedibilidad son aquellas circunstancias que determinan la admisibilidad de la promoción o de la prosecución de la acción penal, y, por ende, constituyen supuestos imprescindibles para el nacimiento y desarrollo de la relación jurídica procesal penal ${ }^{44}$.

En este sentido, los delitos de acción penal pública deben ser promovidos de oficio por parte del Ministerio Público, cualquiera sea el medio o manera como lleguen a su conocimiento. Excepcionalmente, tratándose de delitos de acción penal privada, de acción penal privada previa instancia particular y los delitos que requieren de una autorización de entes estatales, el Ministerio Público no puede promover de oficio la persecución penal sin que antes se cumplan ciertas condiciones de procedibilidad ${ }^{45}$.

Las condiciones de procedibilidad pueden ser privadas o públicas. Las primeras, son aquellas que requieren de la voluntad de un particular para su promoción o ejercicio, como la denuncia de la víctima en el delito de violación de domicilio (artículo 54 del Código Procesal Penal). Las segundas, en cambio, son aquellas que requieren de la voluntad de un agente público, ajeno al órgano persecutor, para que pueda tener lugar el inicio o la prosecución de la acción penal ${ }^{46}$.

La falta de una condición de procedibilidad impide la promoción o prosecución de la acción penal, razón por la cual debe concurrir al momento de su promoción o de su ejercicio, según el caso. En los supuestos de promoción, por tanto, nada de lo que se haga antes de que se cumpla la condición de procedibilidad es válido desde el punto de vista normativo.

43 En la doctrina extranjera también se puede ver esta distinción en: Jescheck, Hans-Heinrich - Weigend, Thomas, Tratado de Derecho Penal. Parte general (Granada, Comares, 2002), p. 981.

${ }^{44}$ NúNÉz VÁsquez, J. Cristóbal, cit. (n. 28), p. 159.

45 Ibid., p. 64.

${ }^{46}$ Ibid., pp. 160-161. 
Luego, la denuncia o querella del Servicio de Impuestos Internos constituye una condición de procedibilidad pública para el inicio de persecución penal de los delitos tributarios ${ }^{47-48}$.

Pero, ¿qué es en realidad un requisito de procedibilidad? En nuestra opinión, es lo que en la doctrina procesal se denomina un presupuesto procesal. El concepto de presupuesto procesal fue expuesto por primera vez por el jurista alemán Bülow en la clásica obra "Die Lehre von den Prozesseinreden und die Prozessvoraussetzungen" de $1869^{49}$.

Como toda relación jurídica, la de naturaleza procesal tiene requisitos de validez. BÜLOW definía a los presupuestos procesales como "las condiciones para la constitución de la relación jurídico procesal" o como "los requisitos a que se sujeta el nacimiento de aquella", o bien "las condiciones previas para la tramitación de toda relación procesal" ${ }^{50}$. Se comprenden bajo esta denominación aquellos elementos formales que se precisan para que una relación procesal surja válidamente. Así las cosas, en su primera versión los llamados presupuestos procesales se referían a todo el proceso y condicionaban la existencia del mismo.

Con todo, de acuerdo con la orientación mayoritaria de la dogmática procesal nacional ${ }^{51}$, se puede definir los presupuestos procesales como aquellas circunstancias formales establecidas por la ley procesal, que deben concurrir en el proceso para que sea posible la resolución sobre el fondo del asunto sometido a la consideración judicial, las cuales, además, deben observarse de oficio ${ }^{52}$.

En el campo del Derecho procesal penal la teoría de los prepuestos procesales se incorporó de inmediato al acervo de la dogmática penal alemana por obra de $\mathrm{Kries}^{53}$, donde fue profundizada en el transcurso del siglo XX,

47 En este sentido, sentencia de la I. Corte de Apelaciones de Santiago, de fecha 15 de abril de 2016, Rol N 1015-2016.

${ }^{48}$ En este sentido lo entiende el Ministerio Público, pero caracterizándola como una acción penal pública previa instancia particular. Cfr. Oficio de la Fiscalía Nacional $N^{\circ} 487$ de 2016, p. 3.

${ }^{49}$ Bülow, Oskar, Die Lehre von den Prozesseinreden und die Prozessvoraussetzungen (1869) (Aalen, Scientia Verlag, 1969), passim.

${ }^{50}$ Ibid., pp. 2 ss.

${ }^{51}$ Por todos ver: Romero Seguel, Alejandro, Curso de Derecho Procesal Civil. La acción y la protección de los derechos (Santiago, Editorial Jurídica de Chile, 2006), I, p. 27.

${ }^{52}$ López Simó, Francisco, La jurisdicción por razón de materia (tratamiento procesal) (Madrid, Editorial Trivium, 1991), pp. 46 ss.

${ }^{53}$ Kries, Agust von, Die Prozessvoraussetzungen des Reichstrafprozesses, en ZStW 5 (1885), pp. 1 ss. 
sobre todo a través de los trabajos de Goldschmidt ${ }^{54}$, Sauer ${ }^{55}$ y Niese ${ }^{56}$. Aún en el presente, el estudio de los presupuestos procesales es considerado útil para trazar la frontera entre el Derecho Penal sustantivo y el procesal. Los impedimentos procesales también representan el instrumento formalprocesal a través del cual se evita la prosecución de un proceso penal en el que faltan los presupuestos de admisibilidad en la persecución ${ }^{57}$.

En palabras de Roxin $^{58}$, los presupuestos procesales en sentido amplio son las circunstancias de las que depende la admisibilidad de todo el procedimiento o una parte considerable de él. Así las cosas, los presupuestos procesales penales se pueden clasificar en atención a tres criterios, a saber: a) los que apuntan a la capacidad jurisdiccional del tribunal; b) los que miran a la perseguibilidad del hecho concreto; y c) los que apuntan a la perseguibilidad del acusado.

Por su parte, respecto del segundo grupo (los relativos a la perseguibilidad del hecho concreto), se puede distinguir los siguientes elementos: 1) El hecho debe estar in tacto, esto es, no puede haber sido ya juzgado o estar pendiente de juzgamiento en otra causa; 2 ) El delito de cuya persecución se trata no puede estar prescrito; 3) La persecución penal no tiene que haber sido clausurada con motivo de una amnistía legal; 4) Tiene que haber una acusación y un auto de apertura de juicio adecuados al ordenamiento jurídico; y 5) En algunos casos, debe existir indispensablemente una instancia de persecución penal o una autorización administrativa.

Conforme lo expuesto, es válido sostener entonces que la querella o denuncia efectuada por parte del Servicio de Impuestos Internos constituye un presupuesto procesal habilitante (presupuesto procesal negativo o impedimento procesal) ${ }^{59}$ para que el Ministerio Público pueda iniciar la investigación de un delito tributario, "y es precisamente el contexto del ordenamiento jurídico vigente (reforzado por el principio de legalidad constitucional) el que impide al Ministerio Público activar sus facultades allí donde no se cumplen, al menos, mínimamente, con las condiciones de aplicabilidad externa de las normas de sanción contenidas en el derecho

${ }^{54}$ Goldschmidt, James, Der Prozess als Rechtlage (Berlin, Springer, 1925), passim.

55 Sauer, Wilhelm, Grundlagen des Prozessrechts (Stuttgart, Enke, 1929), passim.

${ }^{56}$ Niese, Werner, Prozessvoraussetzungen und hindernisse und ihre Feststellung im Strafprozess, en DRZ (1949), pp. 505 ss.

57 Por todos consultar: PAstor, Daniel R., Acerca de los presupuestos e impedimentos procesales y sus tendencias actuales, en VV.AA, Nuevas formulaciones en las ciencias penales. Homenaje al Profesor Claus Roxin (Córdoba, Lerner, 2001), pp. 793 ss.

${ }^{58}$ Roxin, Claus, Strafverfahrensrecht, cit. (n. 20), p. 165.

${ }^{59}$ Constituyéndose como presupuesto de existencia y no de validez o procesabilidad. Ver Romero Seguel, Alejandro, cit. (n. 51), p. 27. 
penal tributario, condiciones entres las cuales se contempla la satisfacción de los requisitos de procesabilidad previstos por los artículos 162 Código Tributario y 54 del Código Procesal Penal"60.

Esta satisfacción de los presupuestos procesales, como señalara BÜLOW, "no puede dejarse librada en su totalidad a la disposición de las partes, pues no se trata de un ajuste privado entre litigantes, sólo influido por intereses individuales, sino de un acto realizado con la activa participación del tribunal y bajo la autoridad del Estado, cuyos requisitos son coactivos y en grandísima parte, absolutos" ${ }^{61}$, por lo que deben, como señala Romero Seguel, observarse de oficio ${ }^{62}$. Así Roxin, en esta misma línea, señala que los presupuestos procesales, deben ser verificados de oficio en cada etapa del procedimiento ${ }^{63}$.

En definitiva, resulta claro que el Ministerio Público está impedido de iniciar investigación alguna por delitos tributarios cuando no exista querella o denuncia previa por parte del Servicio de Impuestos Internos, y si eventualmente ésta igualmente se ha iniciado, el juez de garantía o en su caso el Tribunal Oral en lo Penal, deberá declarar que el proceso es inadmisible, por cuanto, falta un requisito procesal habilitante que impide su persecución, el que, al constituir un presupuesto procesal (de existencia), como hemos dicho, obsta a la formación del proceso.

En este sentido, el Ministerio Público concuerda con que: "la denuncia o querella del Servicio, constituye, de conformidad con nuestro ordenamiento jurídico, un requisito de procesabilidad"64. Sin embargo, caracteriza la acción penal que emana de los delitos tributarios como una de carácter mixta o previa instancia particular ${ }^{65}$, que, como se afirma acá, no es el caso, pues de esta clase de delitos emana una acción penal que requiere autorización de un ente estatal.

Con lo afirmado, surge la necesidad de determinar, por un lado, cuál es la consecuencia de la falta de un presupuesto procesal habilitante, en este caso, la no denuncia o querella. Y por otro, cuál es la herramienta que tiene el contribuyente imputado y en su caso el juez para impedir que el

${ }^{60}$ Salazar Cádiz, Andrés, cit. (n. 2), p. 201.

${ }^{61}$ BüLow, Oskar, cit. (n. 49), p. 293.

${ }^{62}$ Romero Seguel, Alejandro, cit. (n. 51), p. 28.

${ }^{63}$ Roxin, Claus, Strafverfahrensrecht, cit. (n. 20), p. 171.

${ }^{64}$ Instrucción general que imparte criterios de actuación del Ministerio Público en la investigación de los delitos tributarios, en relación con lo dispuesto por el artículo 162 del Código Tributario, oficio $\mathrm{N}^{\circ} 487 / 2016$, p. 3.

${ }^{65}$ Instrucción general que imparte criterios de actuación del Ministerio Público en la investigación de los delitos tributarios, en relación con lo dispuesto por el artículo 162 del Código Tributario, oficio N487/2016, p. 3. 
proceso penal siga adelante ante la falta de denuncia o querella del Servicio de Impuestos Internos.

En nuestra opinión, la falta de un presupuesto procesal como el que venimos analizando, afecta directamente una garantía general del procedimiento, consagrada en el artículo 19 No 3 inciso $6^{\circ}$ de la Constitución Política de la República ${ }^{66}$, a saber, el derecho a un juicio legalmente tramitado. Es decir, el procedimiento que ha de terminar en la dictación de una sentencia debe necesariamente ajustarse a la ritualidad establecida por el legislador, permitiendo consecuentemente la igualdad ante la ley y la certeza jurídica $^{67}$, en definitiva, el respeto al debido proceso. Así las cosas, la inobservancia de un presupuesto procesal, como lo es la omisión de una querella o denuncia (o el incumplimiento de sus requisitos legales) para el inicio de la persecución penal, impedirá la formación de un procedimiento legalmente tramitado, o en palabras de Roxin: "el procedimiento es inadmisible, no se puede dictar una decisión sobre los hechos y el proceso debe terminar" 68 .

En definitiva, la autorización administrativa previa exigida para la persecución penal de los delitos tributarios, se alza como un impedimento u obstáculo procesal, es decir, un presupuesto procesal de existencia, cuya ausencia u omisión producirá necesariamente la inexistencia de la relación procesal $^{69}$.

Ahora bien, planteada la consecuencia de la falta de denuncia o querella como presupuesto procesal, mantenemos el problema de determinar cuál es la herramienta del contribuyente imputado y en su caso del tribunal para impedir que el procedimiento penal siga adelante.

Frente a la omisión de la querella o denuncia, nos encontramos ante la inexistencia procesal, que permite "denotar algo que carece de aquellos elementos que son de la esencia y de la vida misma del acto; un quid incapaz de todo efecto"70. Por tanto, la misma debiese ser constatada por

${ }^{66}$ Artículo $19 \mathrm{~N}^{\circ} 3$ inciso 6o de la Constitución Política de la República: "toda sentencia de un órgano que ejerza jurisdicción debe fundarse en un proceso previo legalmente tramitado. Corresponderá al legislador establecer siempre las garantías de un procedimiento y una investigación racionales y justos".

${ }^{67}$ Roxin, Claus, Strafuerfahrensrecht, cit. (n. 20), p. 166, señala que "los presupuestos procesales serían presupuestos tipificados del aseguramiento de la paz jurídica, sin cuyo concurso no existirían motivos, en realidad, para la actuación del ordenamiento jurídico penal”.

${ }^{68}$ Roxin, Claus, Strafverfahrensrecht, cit. (n. 20), p. 172.

69 Romero Seguel, Alejandro, cit. (n. 51), p. 8.

${ }^{70}$ Couture, Eduardo, Fundamentos del Derecho Procesal Civil (Buenos Aires, Puntolex, 2010), p. 341. 
el tribunal cualquiera sea el estado del procedimiento, ya sea de oficio o a petición de algún interviniente.

Por otra parte, como se trata de un órgano de la Administración del Estado, está sujeto al principio de juridicidad ${ }^{71}$. Luego, sus actos administrativos podrán ser impugnados mediante: $i$ ) un incidente de nulidad de derecho público: que se trata de una cuestión accesoria destinada a declarar la validez o nulidad de un acto del Ministerio Público en razón de su conformidad o disconformidad a Derecho, cuyas infracciones pueden ser: falta de investidura regular, incompetencia, violación de forma o procedimiento, violación de ley y desviación de poder; y ii) cautela de garantías $^{72-73}$.

En consecuencia, el Ministerio Público no está facultado para investigar mientras no cuente con una denuncia o querella por parte del Servicio de Impuesto Internos. A fortiori, tampoco podrá formalizar ${ }^{74}$, no podrá solicitar medidas cautelares ni, en general, provocar la intervención del Juzgado de Garantía. Además, toda prueba reunida adolecerá de ilicitud.

71 "Todo órgano del Estado está sometido al cumplimiento del principio de juridicidad. En efecto, la fórmula "los órganos del Estado" que encabeza el texto de los artículos $6^{\circ}$ y $7^{\circ}$ de la Constitución no establecen excepción alguna. Esto implica que el principio de juridicidad impera sobre todos los órganos del Estado, cualquiera sea la función que desempeñe $(v \cdot g r$., legislativa, judicial, administrativa, contralora, electoral), cualquiera sea la jerarquía que ocupe dentro del orden vertical respectivo, cualquiera sea la extensión territorial sobre la que ejerza su competencia, y, en resumen, cualesquiera sean las características o atributos de que goce. Así, en el régimen chileno de derecho público, no existe excepción alguna a la aplicación del principio de juridicidad.

Por consiguiente, es posible concluir que el Ministerio Público está sujeto integralmente a Derecho, tanto en su ser como en su obrar”. Bocksang Hola, Gabriel, El control de la invalidez de los actos investigativos del Ministerio Público en Informes en Derecho. Doctrina procesal penal (Santiago, Centro de Documentación Defensoría Penal Pública, 2012), pp. 61-83.

${ }^{72}$ Ibid., pp. 76 ss.

73 "En síntesis, el procedimiento penal chileno, de conformidad a los artículos 19 No 3 de la Constitución, $8^{\circ}$ de la Convención Americana sobre Derechos Humanos, y 14 del Pacto Internacional de Derechos Civiles y Políticos no sólo debe garantizar un justo y racional procedimiento, sino también una investigación racional y justa; la impugnabilidad de los actos del Ministerio Público, y en particular de sus actos investigativos, constituye un mecanismo privilegiado de garantía de dichos principios, asegurando la sujeción a control de todos los órganos del Estado, la protección de los derechos de las personas y la unidad del ordenamiento jurídico"; Ibid., p. 83.

${ }^{74}$ Luego, no producirá el efecto de suspender el curso de la prescripción de la acción penal (artículo 233 del Código Procesal Penal). 


\section{LOS DELITOS TRIBUTARIOS Y LA ACCIÓN PENAL}

a) Los delitos tributarios como delitos especiales. El establecimiento de ciertas restricciones típicas respecto del posible círculo de sujetos activos de un delito permite diferenciar los delitos comunes de los delitos especiales ${ }^{75}$. En los primeros, el tipo penal no exige una cualidad especial para ser autor del delito, por lo que cualquier persona que reúna las condiciones generales de imputabilidad podrá responder como autor. En los delitos especiales, en cambio, el tipo penal exige que el autor del delito reúna determinadas características o cualidades especiales. Esta exigencia, a su vez, puede ser expresa (como en el delito de parricidio) o concluyente (como en el delito de defraudación tributaria $)^{76}$.

De esto se sigue que, en el caso de los delitos especiales el sujeto calificado forma parte integrante del tipo penal especial. En efecto, para que se configure el delito se deben reunir todos los elementos típicos, entre ellos, que la persona que realice el hecho punible tenga una determinada calidad exigida por el tipo penal. En consecuencia, si un sujeto que no reúne dicha calidad especial realiza objetivamente la conducta descrita en el tipo, dicha conducta será atípica, por no reunir todos los elementos descritos en el respectivo tipo penal especial. Lo anterior, sin perjuicio de lo sostenido por las teorías sobre la comunicabilidad ${ }^{77}$ y la existencia de otros tipos penales eventualmente aplicables.

En lo que respecta a los delitos tributarios, el artículo 99 del Código Tributario prescribe que: "Las sanciones corporales y los apremios, en su caso, se aplicarán a quien debió cumplir la obligación y, tratándose de personas jurídicas, a los gerentes, administradores o a quienes hagan las veces de éstos y a los socios a quienes corresponda dicho cumplimiento".

Esta norma define al sujeto activo desde una perspectiva invertida ${ }^{78}$ : ya

75 En este sentido, entre otros en Chile: Garrido Montt, Mario, Derecho penal parte general ( $3^{a}$ edición, Santiago, Editorial Jurídica de Chile, 2003), I, p. 73 y Novoa Monreal, Eduardo, Curso de Derecho Penal chileno ( $3^{\circ}$ edición, Santiago, Editorial Jurídica de Chile, 2005), p. 253. Para la doctrina alemana ver por todos: Roxin, Claus, Strafrecht Allgemeiner Teil (München, CH. Beck, 1997), pp. 283 ss. Para España ver por todos: Muñoz Conde, Francisco - García Arán, Mercedes, Derecho Penal. Parte general (5edición, Valencia, Tirant lo Blanch, 2002), p. 261.

76 Vid. García Cavero, Percy, Lecciones de Derecho Penal parte general (Lima, Editorial Jurídica Grijley, 2008), p. 312.

77 Sobre las distintas teorías sobre la comunicabilidad desde la perspectiva de los delitos contra la función pública, ver: Rodríguez Collao, Luis - Ossandón Widow, María Magdalena, Delitos contra la función pública (2a edición, Valparaíso, Editorial Jurídica de Chile, 2008), pp. 127 ss.

${ }^{78}$ Laporta H., Mario, cit. (n. 35), pp. 207 ss. 
que los tipos están redactados de modo que las conductas aparecen como infracciones a obligaciones determinadas, la ley dispone que las penas se aplicarán a quien deba cumplir la obligación en cuestión y, en el caso de las personas jurídicas, a los gerentes, administradores o socios a quienes corresponda el cumplimiento de aquéllas ${ }^{79}$.

En consecuencia, los delitos tributarios ${ }^{80}$ son delitos especiales toda vez que deben ser cometidos por un sujeto calificado, como un contribuyente, un contador o un funcionario público ${ }^{81}$. En otros términos, los tipos especiales del Código Tributario, en relación con el artículo 99 del mismo cuerpo legal, parecen sugerir la idea de que la calidad de contribuyente constituye una característica personal para imponer la pena de autor $^{82}$. Sin embargo, los delitos tributarios relacionados con el comercio informal pueden ser cometidos por sujetos que no revisten tales calidades, mas deberían tenerlas; sin perjuicio de aquellos sujetos que actúan en una doble calidad y utilizan la formalidad de ciertas actividades para encubrir otras ilícitas.

b) Los delitos tributarios y la acción penal. Ahora bien, los delitos tributarios pueden ser caracterizados como delitos especiales, es decir, deben ser cometidos por ciertos sujetos calificados. Pues bien, ¿ello en qué se relaciona con la acción penal que requiere de autorización de un ente estatal?

El Servicio de Impuestos Internos puede discrecionalmente denunciar o querellarse por los hechos que considera son constitutivos de delito tributario, teniendo lugar así la autorización de aquél para proceder penalmente.

Así, al tratarse de un delito especial el sujeto activo forma parte inte-

79 Vid. Van Weezel, Alex, cit. (n. 3), p. 111.

${ }^{80}$ Van Weezel sistematiza las principales figuras penales del siguiente modo: $i$ ) primero, maquinaciones fraudulentas: art. $97 \mathrm{~N}^{\circ} 4$ (disminución engañosa del monto del impuesto), $\mathrm{N}^{\circ} 5$ (omisión de declaraciones), $\mathrm{N}^{\circ} 10$ (reiteración en el no uso o mal uso de documentos), $\mathrm{N}^{\circ} 22$ (mal uso de medios verdaderos de autorización del Servicio), $N^{\circ} 23$ (falseamiento de estado inicial), art. 100 (falsedad y dolo del contador); ii) segundo, quebrantamiento de medidas conservativas y sanciones: art. 97 $\mathrm{N}^{\circ} 12$ (violación de clausura), $\mathrm{N}^{\circ} 13$ (violación de sellos o cerraduras), $\mathrm{N}^{\circ} 14$ (alzamiento de bienes); iii) tercero, actividad económica informal: art. $97 \mathrm{~N}^{\circ} 8$ (comercio ilegal), $\mathrm{N}^{\circ} 9$ (comercio o industria clandestinos), $\mathrm{N}^{\circ} 18$ (comercio ilícito de entradas y fajas de control), $\mathrm{N}^{\circ} 26$ (abastecimiento no autorizado de gas); iv) cuarto, abuso de franquicias y beneficios tributarios: art. $97 \mathrm{~N}^{\circ} 24$ (abuso de beneficios tributarios relativos a donaciones), $\mathrm{N}^{\circ} 25$ (abuso de zonas francas); en VAN WeEzel, Alex, cit. (n. 3), pp. 27-30. Para un estudio de los delitos en particular, ver: Massone Parodi, Pedro, cit. (n. 12), pp. 337 ss. Un panorama sobre las sanciones penales de fraudes fiscales en derecho comparado ver: KHuLEN, Lothar, Cuestiones fundamentales del delito de fraude fiscal (Madrid, Editorial Marcial Pons, 2015), pp. 172 ss.

${ }^{81}$ Laporta H., Mario, cit. (n. 35), pp. 205 ss.

${ }^{82}$ Van Weezel, Alex, cit. (n. 3), p. 118. 
grante del tipo penal. Por ello, debe estar siempre presente en la descripción fáctica de la denuncia o querella, dirigiéndose nominativamente en su contra.

En términos prácticos, si falta un elemento del tipo penal, los hechos denunciados o querellados no son precisos. Así, por ejemplo, si se denuncia a Juan porque "se llevó un reloj", faltan elementos de hecho que permitan subsumir esa conducta en un tipo penal, por lo que tal "comunicación" no podrá ser considerada como una denuncia; no se comunica a través de ella un hecho que sea constitutivo de algún delito. Sí lo sería, en cambio, si lo que se comunica es que "se llevó un reloj que es de otra persona-por ejemplo, de Diego, sin su voluntad, profiriendo amenazas para determinar su entrega" (robo con intimidación). En el caso de un delito especial, el sujeto calificado es parte integrante del tipo penal. Por tanto, si se denuncia que "un sujeto dictó una sentencia, que es contraria a derecho", no se comunica un hecho preciso y, por lo mismo, no se ha tomado conocimiento de un delito. En cambio, si se señala que "el ministro Juan dictó una sentencia fallando contra ley expresa y vigente en una causa criminal", se exponen los elementos típicos del delito de prevaricación (artículo $223 \mathrm{~N}^{\circ} 1$ del Código Penal). Se sabe de antemano quien cometió la conducta, pues la identificación del sujeto es parte integrante del tipo penal que, si no se determina en la denuncia o querella, no se comunica un hecho constitutivo de delito. En el ejemplo, si Juan no es juez, no hay delito.

En el mismo sentido, el Ministerio Público afirma que "no es posible iniciar investigación en contra de persona alguna si no existe, al menos, una descripción minimamente inteligible o precisa de los hechos que se denuncian' ${ }^{\text {'83 }}$. Es más, citando a Mauricio Duce y Cristián Riego, afirma que "los policías se encuentran facultados a rechazar una denuncia en aquellos casos en que aquéllas 'no contengan un relato de hechos con una minima precisión o que, por otra, de la sola relación de los hechos se evidencia que éstos no se enmarcan en uno o más tipos penales"'s4. En consecuencia, si no se ha identificado al sujeto activo en un delito especial, tal hecho no se enmarca en un delito pues falta un elemento típico. Pues bien, para relacionar este delito especial con un sujeto determinado, se requiere de la denuncia o querella del Servicio de Impuestos Internos, pues de lo contrario no se puede proceder criminalmente.

Luego, si se denuncia o querella por un hecho "X» cometido por un sujeto «Y» "y todos quienes resulten responsables" ( $\mathrm{Z} »)$, hay, al menos, dos

${ }^{83}$ Instrucción general que imparte criterios de actuación del Ministerio Público en la investigación de los delitos tributarios, en relación con lo dispuesto por el artículo 162 del Código Tributario, oficio N 487/2016, p. 4.

${ }^{84}$ Ibid., p. 5. 
relaciones (siempre que « $Z$ » sea equivalente a un sujeto; si «Z» corresponde a más de un sujeto, entonces habrá más relaciones): una entre el hecho "X» y el sujeto «Y» y la otra entre el hecho «X» y el sujeto «Z». Así, la relación entre el hecho «X» y el sujeto " $Z$ » indeterminado correría la misma suerte que una denuncia efectuada sin indicar a su autor, pues el sujeto calificado es parte integrante del tipo penal. En consecuencia, la última frase y su relación con el hecho "X» no tiene validez alguna.

En este sentido, en los delitos especiales no cabe denuncia o querella contra persona indeterminada, porque quien lo cometió es parte integrante del tipo penal (delito especial).

Luego, el único acto válido del Servicio de Impuestos Internos es la interposición de una denuncia o querella por un hecho determinado cometido por un sujeto calificado expresamente individualizado.

Si el Servicio de Impuestos Internos no puede actuar válidamente en los términos indicados, a fortiori, tampoco podrá el Ministerio Público iniciar la persecución penal por un hecho descubierto en el contexto de una investigación, pues acá ni siquiera existen hechos querellados o denunciados, ni sujeto calificado. Es más, y como el mismo instructivo del Ministerio Público ordena, por contrapartida de los incisos sexto y séptimo del artículo 162 del Código Tributario ${ }^{85}$, en estos casos se debe oficiar al Servicio de Impuestos Internos para que ejerza la acción penal ${ }^{86}$.

\section{CONCLUSIÓN}

El artículo 162 del Código Tributario otorga al Servicio de Impuestos Internos la facultad privativa y discrecional de ejercer la acción penal por delitos tributarios mediante la interposición de una denuncia o querella.

Dentro de los distintos tipos de acciones, encontramos la acción penal que requiere de autorización de un ente estatal. Como se analizó precedentemente, la acción penal regulada en el artículo 162 del Código

${ }^{85}$ Artículos 162 incisos sexto y séptimo: "El Ministerio Público informará al Servicio, a la brevedad posible, los antecedentes de que tomare conocimiento con ocasión de las investigaciones de delitos comunes y que pudieren relacionarse con los delitos a que se refiere el inciso primero.

Si no se hubieren proporcionado los antecedentes sobre alguno de esos delitos, el Servicio los solicitará al fiscal que tuviere a su cargo el caso, con la sola finalidad de decidir si presentará denuncia o interpondrá querella, o si requerirá que lo haga al Consejo de Defensa del Estado. De rechazarse la solicitud, el Servicio podrá ocurrir ante el respectivo juez de garantía, quien decidirá la cuestión mediante resolución fundada".

${ }^{86}$ Instrucción general que imparte criterios de actuación del Ministerio Público en la investigación de los delitos tributarios, en relación con lo dispuesto por el artículo 162 del Código Tributario, oficio $\mathrm{N}^{\circ}$ 487/2016, p. 5. 
Tributario se trata de una de ellas, la cual tiene reconocimiento implícito en el artículo 264 del Código Procesal Penal. A diferencia de la acción penal previa instancia particular en la que se aplica en delitos que lesionan bienes jurídicos de carácter individual y su fundamento radica en que con la intervención de la víctima ella consiente en la persecución penal, el fundamento de la acción penal que requiere de autorización de un ente estatal se encuentra en el carácter técnico o especializado de su regulación. Así, la determinación de los alcances de un delito tributario envuelve una mayor complejidad que en un delito común pues se debe analizar la regulación tributaria subyacente y determinar su infracción. Esta tarea le corresponde al Servicio de Impuestos Internos a través de un procedimiento administrativo denominado recopilación de antecedentes. Luego, éste podrá adoptar la decisión de interponer o no denuncia o querella por la eventual comisión de un delito tributario.

Desde otra perspectiva, la acción penal que requiere de autorización de un ente estatal consiste en un presupuesto procesal de perseguibilidad. Éstos consisten en elementos formales que se precisan para que una relación procesal surja válidamente. Luego, el Ministerio Público está impedido de iniciar investigación alguna por delitos tributarios cuando no exista querella o denuncia previa por parte del Servicio de Impuestos Internos, y si eventualmente ésta igualmente se ha iniciado, el juez de garantía o en su caso el Tribunal Oral en lo Penal, deberá declarar que el proceso es inadmisible, por cuanto, falta un requisito procesal habilitante. Por tanto, en el primer caso se podría intentar una cautela de garantías o nulidad de derecho público, mientras que en el segundo caso se deberá requerir al Tribunal un pronunciamiento sobre el particular en caso de que no lo hubiese realizado de oficio. En consecuencia, el Ministerio Público no está facultado para investigar mientras no cuente con una denuncia o querella por parte del Servicio de Impuesto Internos. A fortiori, tampoco podrá formalizar, no podrá solicitar medidas cautelares ni, en general, provocar la intervención del Juzgado de Garantía. Además, toda prueba reunida adolecerá de ilicitud.

Ahora bien, los delitos tributarios pueden ser caracterizados como delitos especiales toda vez que deben ser cometidos por un sujeto calificado, como un contribuyente, un contador o un funcionario público. Sin embargo, ¿ello en qué se relaciona con la acción penal que requiere de autorización de un ente estatal? Como se estudió en el respectivo apartado, el sujeto activo forma parte integrante del tipo penal. Por ello, debe estar siempre presente en la descripción fáctica de la denuncia o querella, dirigiéndose nominativamente en su contra. Así, en los delitos especiales no cabe denuncia o querella contra persona indeterminada, porque quien 
lo cometió es parte integrante del tipo penal. En consecuencia, el único acto válido del Servicio de Impuestos Internos es la interposición de una denuncia o querella por un hecho determinado cometido por un sujeto calificado expresamente individualizado.

En nuestra opinión, la institución de la acción penal que requiere de autorización de un ente estatal es útil al sistema de enjuiciamiento criminal, ya que permite que un órgano especializado inquiera los extremos del incumplimiento de una obligación tributaria que subyace a la comisión de un delito tributario. Si bien el artículo 162 del Código Tributario ha sido objeto de gran debate en el último tiempo, parece ser que la crítica está relacionada más bien con la independencia de la decisión a adoptar por parte del Servicio de Impuestos Internos que con la institución en sí. Al respecto, sólo recordar que la Contraloría General de la República señaló recientemente que "las autoridades y funcionarios del SII están obligados a observar el principio de imparcialidad consagrado en el artículo 11 de la ley $\mathrm{N}^{\circ} 19.880$, conforme al cual, tanto en la substanciación de sus procedimientos como en las resoluciones que adopten, han de actuar con objetividad y respetar el principio de probidad, el que, a su vez, les impone la obligación de emplear medios idóneos de diagnóstico, decisión y control, según lo ordena el artículo 53 de la ley $\mathrm{N}^{\circ} 18.575^{\prime 87}$.

\section{BiBLIOGRAFÍA}

Bellavista, Girolamo - Tranchina, Giovanni, Lezione di Diritto Processuale Penale (10 edición, Milano, Giuffrè, 1987).

Bermúdez, Jorge, Derecho Administrativo general (2a edición, Santiago, LegalPublishing, 2011).

BINDER, Alberto, Introducción al Derecho procesal penal (2a edición, Buenos Aires, Ad Hoc, 2000).

Bocksang Hola, Gabriel, El control de la invalidez de los actos investigativos del Ministerio Público en Informes en Derecho. Doctrina procesal penal (Santiago, Centro de Documentación Defensoría Penal Pública, 2012).

Bülow, Oskar, Die Lehre von den Prozesseinreden und die Prozessvoraussetzungen (1869) (Aalen, Scientia Verlag, 1969).

Carocca Pérez, Álex, Manual. El nuevo sistema procesal penal (4a edición, Santiago, LexisNexis, 2008).

Castillo Blanco, Federico, La protección de la confianza legitima en el Derecho Administrativo (Madrid, Editorial Marcial Pons, 1998).

Castro Jofré, Javier, Introducción al Derecho Procesal Penal chileno (2a edición, Santiago, LegalPublishing, 2008).

${ }^{87}$ Dictamen $\mathrm{N}^{\circ} 14.000$, de 27 de abril de 2017. Disponible [en línea]: http:// www.contraloria.cl/LegisJuri/DictamenesGeneralesMunicipales.nsf/FormImpresio nDictamen?OpenForm\&UNID=64788584B95131810325810C0048EA96, p. 4. 
Chahuán SARras, Sabas, Manual del nuevo procedimiento penal (7a edición, Santiago, LegalPublishing, 2012).

Chiavario, Mario, Appunti sul processo penale (Torino, Giappichelli, 2000).

Chiavario, Mario, L'azione penale tra e Diritto e Politica (Padova, CEDAM, 1995).

Cordero, Franco, Procedure Penale (5º edición, Milano, Giuffrè, 2000).

Correa Selamé, Jorge, Curso de derecho procesal penal (Santiago, Ediciones Jurídicas de Santiago, 2003).

Couture, Eduardo, Fundamentos del Derecho Procesal Civil' (Buenos Aires, Puntolex, 2010).

Dominioni, Oreste, Azione Penale, en Digesto della Discipline Penalistiche (Torino, UTET, 1987).

Duce Julio, Mauricio - Riego Ramírez, Cristián, Proceso penal (Santiago, Editorial Jurídica de Chile, 2007).

García Cavero, Percy, Lecciones de Derecho Penal parte general (Lima, Editorial Jurídica Grijley, 2008).

Garrido Montt, Mario, Derecho penal parte general (3a edición, Santiago, Editorial Jurídica de Chile, 2003), I.

Gimeno Sendra, José Vicente, La querella (Barcelona, Bosch, 1977).

Goldschmidt, James, Der Prozess als Rechtlage (Berlin, Springer, 1925).

Hassemer, Winfried, Lineamientos de una teoría personal del bien jurídico, en Doctrina Penal (1989).

Herzog, Felix, Gesellschaftliche Unsicherheit und strafrechtliche Daseinsvorsorge (Heidelberg, RV. Decker, 1991).

Hohmann, Olaf, Das Rechtsgut der Unweltdelikte (Frankfurt, Peter Lang, 1991).

Horvitz Lennon, María Inés - López Masle, Julián, Derecho procesal penal chileno (Santiago, Editorial Jurídica de Chile, 2002), I.

Jescheck, Hans-Heinrich - Weigend, Thomas, Tratado de Derecho Penal. Parte general (Granada, Comares, 2002).

Kaufmann, Hilde, Strafanspruch, Strafklagerecht (Göttingen, Otto Scwartz Verlag, 1968).

KHUlEN, Lothar, Cuestiones fundamentales del delito de fraude fiscal (Madrid, Editorial Marcial Pons, 2015).

KrIEs, Agust von, Die Prozessvoraussetzungen des Reichstrafprozesses, en ZStW5 (1885).

Laporta H., Mario, Delito fiscal. El hecho punible, determinación del comportamiento típico (Buenos Aires, B. de F., 2013).

Leone, Giovanni, Azione penale, en Enciclopedia del Diritto IV (Milano, Giuffrè, 1958).

López Simó, Francisco, La jurisdicción por razón de materia (tratamiento procesal) (Madrid, Editorial Trivium, 1991).

Maier, Julio, Derecho procesal penal (Buenos Aires, Editores del Puerto, 2004).

Massone Parodi, Pedro, Infracciones tributarias (2a edición, Santiago, Legal Publishing, 2010).

Maturana Miquel, Cristián - Montero López, Raúl, Derecho procesal penal (Santiago, LegalPublishing, 2010), I.

Medina Jara, Rodrigo - Morales Palacios, Luis - Dorn Garrido, Carlos, Manual de derecho procesal penal (2a edición, Lexis Nexis, Santiago, 2007).

Morello, Michele, Il nuovo processo penale. Parte generale (Padova, CEDAM, 2000).

Muñoz Conde, Francisco - García Arán, Mercedes, Derecho Penal. Parte general (5 edición, Valencia, Tirant lo Blanch, 2002). 
NIESE, Werner, Prozessvoraussetzungen und-hindernisse und ihre Feststellung im Strafprozess, en DRZ (1949).

Novoa Monreal, Eduardo, Curso de Derecho Penal chileno ( $3^{\circ}$ edición, Santiago, Editorial Jurídica de Chile, 2005).

NúÑEz VÁsquez, J. Cristóbal, Tratado del proceso penal y del juicio oral. Introducción al estudio del proceso penal (Santiago, Editorial Jurídica de Chile, 2003).

Oliver Calderón, Guillermo, Apuntes de Derecho Procesal Penal (Valparaíso, inédito, 2017).

Otero Lathrop, Miguel, La policía frente al Código Procesal Penal (Santiago, Editorial Jurídica de Chile, 2010).

PASTOR, Daniel R., Acerca de los presupuestos e impedimentos procesales y sus tendencias actuales, en VV.AA, Nuevas formulaciones en las ciencias penales. Homenaje al Profesor Claus Roxin (Córdoba, Lerner, 2001).

Piedrabuena Richard, Guillermo, Las potestades del Ministerio Público en la investigación de los delitos tributarios, en Revista de Derecho del Consejo de Defensa del Estado 33 (2015).

Piedrabuena Richard, Guillermo, Las potestades del Ministerio Público en la investigación de los delitos tributarios, en Revista de Derecho Público 85 (2016).

Riccio, Giuseppe, Azione penale e politica delle reforme, en Arch.pen (1992).

Rodríguez Collao, Luis, Delitos sexuales (2a edición, Valparaíso, Editorial Jurídica de Chile, 2014).

Rodríguez Collao, Luis - Ossandón Widow, María Magdalena, Delitos contra la función pública (2a edición, Valparaíso, Editorial Jurídica de Chile, 2008).

Romero Seguel, Alejandro, Curso de Derecho Procesal Civil. La acción y la protección de los derechos (Santiago, Editorial Jurídica de Chile, 2006), I.

Roxin, Claus, Strafrecht Allgemeiner Teil (München, CH. Beck, 1997).

Roxin, Claus, Strafverfahrensrecht (25 edición, München, CH. Beck, 1998).

SAlAZAR CÁDIZ, Andrés, Acerca del inicio del proceso penal por delitos tributarios: análisis de la posición del profesor PIEDRABUENA en relación con las facultades de investigación del Ministerio Público en ausencia de querella o denuncia del Servicio de Impuesto Internos, en Revista Jurídica del Ministerio Público 66 (2016).

SAUER, Wilhelm, Grundlagen des Prozessrechts (Stuttgart, Enke, 1929).

Silva Montes, Rodrigo, Manual de procedimiento penal (Santiago, Editorial Jurídica de Chile, 2001).

Silva Salse, Manuel, Diligencias de investigación limitativas de derechos fundamentales o intrusivas otorgadas a la Fiscalía Nacional Económica, en Revista de Filosofía y Ciencias Jurídicas 7 (2015).

Sото KLoss, Eduardo, Acerca de la obligatoriedad de los precedentes en la actividad administrativa del Estado, en Revista Chilena de Derecho 26, (1999), 2.

TAORmina, CARLO, Vecchio e nuovo nella teoria dell'azione penale» alle soglie del nuovo codice di procedura, en La Giustizia Penale (1988).

Tonini, Paolo, Manuale di procedura penale (Milano, Giuffrè, 1999).

Torres Rosell, Nuria, La denuncia en el proceso penal (Madrid, Montecorvo, 1991).

VALENTINi Reuter, Cristina, Le forme di controllo sull'esercizio dell'azione penale (Padova, CEDAM, 1994).

Van Weezel, Alex, Delitos tributarios (Santiago, Editorial Jurídica de Chile, 2007).

Vélez Mariconde, Alfredo, Derecho Procesal Penal (Córdoba, Lerner, 1986), I. 
Vila Baltra, Martín, Titularidad de la acción penal en los delitos tributarios, en Anuario de Derecho Tributario 7 (2015).

VolK, Klaus, Strafprozeßrecht (München, CH. Beck, 1999).

ZIPF, Heinz, Strafantrag, Privatklage und staatlicher Strafanspruch, en GA (1969). 